\title{
Fall of the Berlin Wall: Reflection of the Historical Event in the Newest German Drama
}

\section{Caída del muro de Berlín: reflejo del acontecimiento histórico en el drama alemán más reciente}

\author{
Anzhela Rafizovna Lisenko* \\ Kazan Federal University, Russia \\ ORCID: https://orcid.org/0000-0003-3994-7106 \\ Ilmira Mukharyamovna Rakhimbirdieva \\ Kazan Federal University, Russia \\ ORCID: https://orcid.org/0000-0001-9915-0065 \\ Rezida Iskandarovna Mukhametzyanova \\ Kazan Federal University, Russia \\ ORCID: https://orcid.org/0000-0002-3614-1716
}

Received 09-08-20 Revised 10-10-20

* Correspondence

Email: anzhela.amirova@gmail.com
Accepted 20-12-21 On line 02-20-21

Citation:

Anzhela Rafizovna Lisenko, Ilmira Mukharyamovna Rakhimbirdieva, Rezida Iskandarovna Mukhametzyanova (2021). Fall of the Berlin Wall: Reflection of the Historical Event in the Newest German Drama. Propósitos y Representaciones, 9(SPE2), e1017. http://dx.doi.org/10.20511/pyr2021.v9nSPE2.1017 


\section{Summary}

In this article, the authors refer to the play "Kein Schiff wird kommen" ("No ship will come"), 2010, by a young German playwright Nisa-Momme Stockmann, in which "historical events are refracted in the context of personal events of the characters". In the center of the play is a young man, a writer, who was commissioned by the theater to write about the fall of the Berlin Wall. The protagonist of the play is a representative of an indifferent generation, far from politics and history. In 1989, he himself was a child, and the reunification of Germany, at first glance, had no effect on him. However, upon closer inspection, it turns out that the fall of the wall turned out to be an important event for him and his family. Only an appeal to the history of the country and the family helps the character to resolve the internal conflict. This shows the relationship with the tradition of German literature after World War II: German writers often refer to historical facts in their works. The key topic is of guilt and responsibility, which has been rethought in the literature over the past 60 years. Analysing the drama allows us to conclude that modern young people reject their past, which causes the character's personality crisis, and it also leads to failure in communication. In addition, alongside with ousting the past, the problem of German identity arises.

Keywords: communication, history, cultural identity, theatre, literature, drama

\section{Resumen}

En este artículo, los autores se refieren a la obra "Kein Schiff wird kommen" ("Ningún barco vendrá"), de 2010, de la joven dramaturga alemana Nisa-Momme Stockmann, en la que "los acontecimientos históricos se refractan en el contexto de acontecimientos personales de los personajes ". En el centro de la obra hay un joven, un escritor, a quien el teatro le encargó que escribiera sobre la caída del Muro de Berlín. El protagonista de la obra es un representante de una generación indiferente, alejada de la política y la historia. En 1989, él mismo era un niño, y la reunificación de Alemania, a primera vista, no tuvo ningún efecto en él. Sin embargo, después de una inspección más cercana, resulta que la caída del muro resultó ser un evento importante para él y su familia. Solo una apelación a la historia del país y la familia ayuda al personaje a resolver el conflicto interno. Esto muestra la relación con la tradición de la literatura alemana después de la Segunda Guerra Mundial: los escritores alemanes a menudo se refieren a hechos históricos en sus obras. El tema clave es la culpa y la responsabilidad, que ha sido repensado en la literatura durante los últimos 60 años. Analizar el drama nos permite concluir que los jóvenes modernos rechazan su pasado, lo que provoca la crisis de personalidad del personaje y también conduce a fallas en la comunicación. Además, junto con la expulsión del pasado, surge el problema de la identidad alemana.

Palabras clave: comunicación, historia, identidad cultural, teatro, literatura, drama.

\section{Introduction}

The opening of the borders between East and West Berlin in November 1989 was a turning point in the history of the 20th century, which completed the era of the existence of the socialist camp in Europe. After the reunification of Germany and the destruction of the USSR in a world that was divided over long years into two opposing camps, the concept of globalization acquired great importance. The world began to live according to new laws and it affected not only the countries of the former socialist camp. The view of life changed significantly and a change of values took place. For forty years, people who lived "behind the Iron Curtain" and had not build communism, who had long been disappointed in the policies of their states, suddenly found their long-awaited freedom. The reunification of Germany closed the long "post-war period" and summed up a peculiar result of the whole century. However, the euphoria associated with new political events did not last long. After some time, it became clear that another change in the political system has not brought universal welfare. Inflated expectations have not come true. The inhabitants of East 
Germany, attached to the Federal Republic of Germany, were forced to adapt not only to the new political, but also social and economic conditions. Many people lost their jobs, in search of a better life, they went to the more successful "old" federal lands, which lead to overpopulation of cities in the western part of the country and the devastation of the territory of the former GDR. There were conflicts between the Ossies and the Wessies (East and West Germans).

After German reunification, German drama themes include, on the one hand, understanding of modern reality: the place of a human being in the new world, the multiculturalism of society, the consequences of the removal of borders for a "little man" (not only political, but also often moral borders) on the other hand, rethinking of the German and world history of the 20th century (Lisenko, Shevchenko 2016). In this case, the authors sometimes are interested in timeless problems - a person at the moment of making a vital decision, the correlation of the historical truth and a myth, the role of woman in political struggle, the relationship of the executioner and the victim (D. Loher "Olga's Room", "Leviathan", etc.), sometimes - in the actual "German fate" (M. von Mayenburg "Der Stein" ("Stone") and sometimes - in the problem of self-identification and German identity (A.Ostermaier "Vatersprache" ("Father's language"), N.-M. Stockmann "Kein Schiff wird kommen" ("The ship will not come"). Comprehension of modern reality and rethinking of the German history of the 20th century are becoming important themes of German drama at the turn of the XX - XXI centuries. However, unlike the drama of the previous decades, it is not the historical events themselves and attitudes toward them that come to the fore, but the people inside these events (Schröder, 2006). History becomes the background for events taking place with an individual. The new generation of playwrights, referring to history, still turns its face to the present, but at the same time it adopts the entire arsenal of various innovative, experimental forms and techniques created by the previous era. And, by the way, it also features in the new Russian drama (see T. Prokhorova, V. Shamina; V. Zavyalova).

\section{Methods}

In this article, the authors refer to the play of a young German playwright Nis-Momme Stockmann "The Ship Will Not Come" (the play opened in 2010) where he dwells upon one of the most significant historical events of the late 20th century, the fall of the Berlin Wall and the reunification of Germany.

If we turn to the German drama of the late twentieth century, namely, the post-perestroika period, it becomes obvious that the topic of the recent past of Germany was not exploited often. Understanding the history of the 20th century and the wide range of problems associated with it power and personality, life under dictatorship, mechanisms of violence, forms of unfreedom, intellectuals and power, the universal nature of the correlation of forces on the historical arena, etc. - were in the center of creativity of the outstanding playwright H. Muller, who passed away in 1996 (Shevchenko, 2006). In 1989, another major German playwright, B. Strauss, wrote the play "The Final Choir" ("Schlußchor"), in which in an encrypted, metaphorical form, he recreates the picture of German reunification, destroying the official myth of the long-awaited by Germans national identity (Shevchenko, 2009).

As for the rest, the theater of Germany did not respond to the fateful events of the newest German history with the active interest that was expected of it. Apparently, a certain time distance was required, which was necessary for understanding what was happening, and the experience of living in a reunited Germany. Recently, young German authors, who came to the drama in the 90s, are increasingly turning to the history of their country.

It should be noted that the theme of the reunification of Germany and the fall of the Berlin Wall, to which N.-M. Stockmann refers, is widely represented in German cinema. In the 90s and 2000s, a large number of feature films about the life of Germans in the period before and after the reunification were shot with personal stories amidst the world historical events (see Pedersen).

\section{Results and Discussion}


The young playwright Nis-Momme Stokmann in his play "The Ship Will Not Come" refers to the recent past - the fall of the Berlin Wall. N.-M. Stockmann was born in 1981 on the island of Föhr (Germany), he studied in Hamburg, Odense (Denmark) and Berlin, since 2009 he has been a fulltime playwright of the Frankfurt Schauspiel Theater ("Das Schauspiel Frankfurt"). Stockmann is a laureate of various festivals of modern drama, in 2010 he was called by the "Theater Heute" magazine as the best young theater playwright. His play "The Ship Will Not Come", as already mentioned, refers to the already historic event of 1989 - the fall of the Berlin Wall. At the same time, the play deals with the life of a modern writer who works for his employer and he does not write about the things interesting for him, but in accordance with market demand. According to R. Dolzhansky, the play gives "a merciless and desperate self-analysis of another "lost generation" amidst the thoughts about the fate of the whole country" (Dolzhansky, p. 13). The intense emotional background of the play is enhanced by the dramatic relationship between the father and the son, who, while reflecting on the history of the country, are trying to find their place in it and forge their own relations.

The drama is epic in nature and is a story by a young writer, recorded on a dictophone, about the creation of a play, the text of which is included in the drama. Making the drama texts epic is an important feature of the newest drama. In front of us there is not an action, but a story about it, recorded on tape, with a prologue and an epilogue. This creates an even greater distance of the viewer / reader in relation to what is going on in the play.

There is a sense of autobiography in the play. The young author is commissioned by the theater for which he works to write a play "on the topic of the day" - about the $20^{\text {th }}$ anniversary of the fall of the Berlin Wall. Nameless writer does not care about the events of those years. He learned about the existence of the Wall only in high school and he never thought about its significance for the country and people. He is a representative of a generation far from politics and history. For him, the Wall is only a "showcase topic", the fall of the Wall is "a demagogic simplification of many things" (Stockmann, p. 469), which "really got to all Germany" (Stockmann, p. 439). The life of a young writer is a set of daily recurring meaningless actions: smoking a cigarette / playing online games / drinking beer on Skype, all his "daily supply of energy" is spent on drying hair (Stockmann, p. 448). He describes his life with short phrases, plain sentences, which emphasizes even more the meaninglessness of his existence. Such image of a writer is not new in contemporary literature. For example, everyday life of a poet in The Enderby Novels by A. Burgess represents almost the same (E. Smyslova, L. Khabibullina, p. 82).

The assignment received by the writer from the theater is a "big topic" with which the young author is invited to "grow." The contemporary theater, according to its authorities, lacks "scale", because the authors write only about "pedophiles, lesbians in a love triangle, arguing about artificial insemination, rape in marriage" to express their thought, "which can actually be retold in one sentence" (Stockmann, p. 433). Writing such a "large-scale" work turns out to be very difficult for the hero of the play. Scale in his imagination is associated with Heidegger and Hitler, who "play cards with Nietzsche in the Hell" (Stockmann, p. 434), but in fact he describes in his dramas scandalous situations that have recently become commonplace, "the things people want to hear" (Stockmann, p. 433). However, he feels a certain pride in the realization that he is a writer. He calls himself "high flier" because he lives and works in Berlin (Stockmann, p. 448). He sees his work as his mission, a way to improve the world, although in reality he simply takes his lead from the audience and the market. He contrasts himself to his relatives, ordinary people, whose world is "sideboards, flowers in pots and pale pink curtains" (Stockmann, p. 432). At the same time, he admits that he fears these people, "as any writer fears everyday life", although it's there where we can find the truth. It was not accidental that in one of the dialogues with the publisher he mentions Ibsen, who reflects "big themes" in the life of certain families.

To collect material for the new play, the writer goes to his father on the island of Föhr, to the north of Germany. His father witnessed the fall of the Berlin Wall, therefore, according to the writer, his father's impressions could form the basis of the play. In addition, his mother, who died in the early 90s, originated from East Berlin, the fact which was supposed to make the play even more fascinating. Long conversations with his father about the past, recorded on the dictophone, 
have not lead to a quick writing of a documentary play. Meeting with the past leads to the character's internal conflict, causing a creative and life crisis, turning into a "search for the lost epoch" at the beginning of the 21 st century. Problems in building communication with his father intensify the conflict (see S. Takhtarova, D. Abuzyarova, O. Kuzmina; S. Takhtarova, R. Khairutdinov, D. Abuzyarova).

The conflict between the father and the son lies primarily in the unwillingness of the latter to remember the past. His "forgetting" is intentional. He not only knows nothing about the Wall and the events of those years, he consciously "forgot" everything. After talking with his father about the past in the house where the hero of the play spent his childhood and where his mother died, he is forced to return to the events of twenty years ago, and he ceases to understand what is left in him of the present, not read from other people's books, but of experienced and keenly felt things. The motive of forgetting becomes, along with the motive of time, leading in the play, appearing already in the prologue, when the writer admits that he "forgot a lot of important things," when he forgets to visit his grandmother, he forgets the episodes of his childhood. His mother becomes ill with Alzheimer's disease, which means "forget everything" (Stockmann, p. 464), and it is this memory that becomes the most difficult for the hero, and getting rid of it, he forgot everything else.

Unlike him, his father is not ready to give up his past. Enjoying the arrival of his son, he constantly recalls minor episodes from his childhood. Every time he asks him what pizza he wants, although he knows it perfectly well. Repetitions of the same details and events seem to bring him back to the past, which his son is so keen to push away from himself. For his father, Föhr Island is a home, a place where he can be equally proud of not only his son-writer working for the Berlin theatre, but also the son who glorified his car when he was a child. For his son, Föhr is "14 years of beaches / 14 years of dunes / 14 years of reeds / 14 years of the cinema closed for the winter / And dried flowers / And dirty pants / Drunkards sleeping in the corners" (Stockmann, p. 436). The son is always in a bad mood when he arrives in the island. The father is always in the "excellent mood" when the son comes. However, no matter how hard the son tries to get rid of the memories, they break through, for example, in his dreams, or "when the booze went well" (Stockmann, p. 435). He recalls the feeling of happiness that he experienced as a child, and with bitterness realizes that this will not happen again. He thinks that his father is already old and may die soon, and that everything around him "dies and fades in the light of time that will never return" (Stockmann, p. 437). The father, like his home, gives rise to conflicting feelings in his son. They are pity and love, pride and disgust. He says, "This is a wonderful man (who infuriates me so much)" (Stockmann, p. 435).

The fall of the Wall for the father is part of his personal story, it was in 1989 that his wife's illness began, "the whole story with our mother" (Stockmann, p. 442). In his story about that time, he repeats several times that his son does not understand what was happening to people then. It was the time of the generation capable of rebellion, whereas all the activities of the modern generation are directed only at making money. "You do not understand what a market is," the son says for several times. The generation of children strives to simplify their lives as much as possible and in this it goes to the denial of all values, reducing it to work and empty entertainment like alcohol and the Internet. The son acknowledges the futility of his existence, but when his father offers to rebel, he replies that he does not have time for this, since he needs to earn money to "live somehow" (Stockmann, p. 446). In fear that his plays will not be staged, he tries in them to "avoid extremes and take a middle course" (ibid.). It turns out that his whole life is a vicious circle, the desire to conquer everyday life goes along with the reluctance of the struggle itself. He says: "We already want Germany to wage a war. The war for new themes" (ibid.), but that war, in his opinion, must be started by someone else, so that he himself could stand aside. Thus, the wall, destroyed by the protesting generation of the late $80 \mathrm{~s}$, is re-erected in the thoughts of the 2000s generation. Father's call to rebel and take the risk is not heard. It is noteworthy that the father accuses his successful son of being childish. "When will you finally grow up?" he asks. The infantilism of the modern young generation is regarded by many psychologists and sociologists. Young people are not in a hurry to give up the children's worldview, responsibility for their own actions and the need to make decisions is burden to them. That is why the hero of the Stockmann's 
play gives up his memories: children who have lived not so long have nothing to remember. One of the signs of infantilism is egoism: the son makes the father talk about personal tragedy in order to earn money on it. Life on the island becomes unbearable for a young writer, because here, far from the bustle of the city, he has time to think, he is left alone with his thoughts, forced to analyze his life. And it seems to him that it is much easier to drop the memories and thinking of his real problems, rather than to try to find their solution. "It's not my thoughts, where on Earth did they come from?" he exclaims (Stockmann, p. 451).

The end of the 80 s for the son is not the time of change, as it was for the generation of fathers. It was just the "era of cheap and poisonous synthetics" (Stockmann, p. 449). Only this is for him the "spirit of that epoch". A playwright with no feelings is unable to write a play. And then his internal contradictions develop into a personality crisis. He understands that "something is wrong" with him, he begins to realize the personal responsibility for his generation: "My generation is responsible for its cultural product - it means that I am also responsible for it. Moreover, since I know everything, since I know the inside of this comedy, it turns out that it's my responsibility. ... Money and responsibility. Money and responsibility. Money and responsibility" (Stockmann, p. 452). The realization that being a writer, it is he who must lead his generation forward, makes him accept his past. "Well, Dad," he calls out to his father, "I need your help. Or that's it for me. I miss skin and flesh. I want so much to be human again" (Stockmann, p. 455). The generation gap is overcome at the moment when the hero realizes that he cannot live without the past. It is as if he allows himself, finally, to remember his mother and her last days before her death, at the time when the Berlin Wall was collapsing. In his sleep, she asks him a question: "Does the world have nothing more to give you, or it's you who don't need anything?" (Stockmann, p. 453) and after that he gives free rein to his memories, with which natural human feelings come.

The father helps him to remember the last days of his mother. In the Stockmann's drama, the memories of two heroes - the father and the son - are presented in the form of text in the text. The young writer had succeeded in writing a play, but it was not about the fall of the Wall, but about the death of his mother and reunion with his father. The image of the mother becomes a symbol of memory, of universal knowledge. His mother losing her memory and reason because of Alzheimer's disease tells her five-year-old son how important it is to remain human, to keep feeling and remembering: “... people are stingy, dumb and standout. ... It all starts in you. You yourself generate it. This is you. That's you. Madness. You see. To know everything. That's you. You make this world unbearable. And everything wants something from you. YOU. You are the temple ... and the flesh and the reason. You are different from everything else. ... And everything has consequences in our present life, and there is no return back" (Stockmann, p. 465). Thus, the position of her son's disengaging from everything turns out a dead end. No matter how hard he tries to stay away, he fails. The play of the young author ends with reunion with his father:

Father. Sonny, your mother died.

Son. For the first time in our lives, nothing set apart us. And I had a feeling: a new time is coming. And the new freedom (Stockmann, p. 467 - 468).

So, having written a play about himself, his mother and father, voicing the tragic memories that link them, the Stockmann's hero begins to look at his life in a new way. The generation gap is overcome, the son overcomes his infantilism and transits into the world of adults. Now his conversations with his father are more relaxed, they continue to discuss the same topics as before, but now the son is listening to his father. There are no remarks pointing to the actors in the play, so it is sometimes difficult to understand whose line is it. It is especially difficult to do this in the last scenes, when the son is reunited with his father and their thoughts flow into each other. In the epilogue, the son recalls some joyful moments of a joint past with his father. Once again they talk about the fall of the Wall and the question arises about German identity. The son says that although he is a German, in his worldview "the fall of the Wall does not play any role. Just like for millions of Germans" (Stockmann, p. 472), to which the father responds: "Well, in this sense, it really does not play any role" (Stockmann, p. 473). Father's answer is ambiguous. On the one 
hand, the wall could not divide an integral German nation (it's not by chance that the text of the play several times states that the mother originated from East Berlin). On the other hand, the destroyed wall did not bring solutions to old problems, but, on the contrary, caused new ones. We are talking not only about the situation in Germany after the reunification, but also about the world history of the end of the 20th - beginning of the 21st century, with acts of terrorism, economic crises, and nationalist movements. According to I. Uberman, in his play Stockmann shows that "wenn die älteren Deutschen heute behaupten, es sei das wichtigste und glücklichste Ereignis in ihrem Leben, dies unwahr ist $<\ldots>$ sie waren oft vor allem mit dem eigenen Alltag beschäftigt" ("when the older Germans claim that this was the most important and happy event in their life, they are not telling the truth [...] at that time they were, first of all, preoccupied with themselves"). (Uberman)

In addition to resolving the conflict with his father, the son finds a way out of the creative crisis. He understands, "Everyone who creates our culture, I mean the elite, those who are at the very top, ... is a bunch of indifferent, emotionally stupefied, socially perverted neurotics, who don't have a single tear, not a single smile for what they themselves are talking about. The problem, in fact, is that creativity has become a routine for them. They themselves are unable to feel anything ..." (Stockmann, p. 470). If earlier he referred himself to such "elite", now he seems to break with them using the pronoun "they". He is not afraid of everyday life any more, the thing his father accused him of at the beginning of the play, he confesses in his ability to love. He does not publish the commissioned play about the fall of the Wall.

The only conflict that remains unsolved is the inner conflict of the character. Revived memories made him take a fresh look at his life and once again realize its worthlessness. Now he does not waste time senselessly on idle pleasures and his existence is not subject to the only objective of making profit. He recalls again and again "the linden, the terrapin, the couch and the nameless red cat", the images of his childhood associated with his mother, and he sees only hopeless mediocrity around him. He blames himself for not saying much to his father, not hugging him or clapping him on the shoulder. He looks into himself and sees the emptiness inside. He is suffering, close to the suffering of his mother: "I have had enough of it, I'm fed up. I stand by the water. Stars shine over me. This is pure mockery. All this hope and freedom" (Stockmann, p. 474).

\section{Summary}

Thus, in the Stockmann's play the image of the young generation with no other values and life orientations than money, not knowing its past and realizing its involvement in it, is presented. The resolution of the conflict in the play is in transition of a representative of children's generation into adults' generation. The hero of the play takes over the spiritual suffering of his mother and remains one-on-one with himself in the final of the play. He learned to see history, "his giant mediocre past," and at the same time to see himself. But this vision opens his eyes to the world around him, which is no longer interesting to him, "But apart from that, I see nothing." The final line reflects the pessimistic perception of the world, typical of most modern playwrights.

\section{Conclusions}

In conclusion, it should be noted that contemporary young playwrights continue the tradition of their predecessors and regard the generation gap in the context of the theme of memory. The past is inextricably linked with the present, a generation of children will once become a generation of fathers and enter into another confrontation, now with their children. In this sense, the attitude towards memory becomes especially important. The memory of the past is an inseparable part of the present. Heroes who do not know their past will certainly have a problem of their own identity. The young writer in the Stockmann's play, for a long time resisting the past, becomes a selfish and insensitive representative of a generation of children who are not capable, in contrast to fathers, of any significant deeds. "Seeing himself" became possible only by referring to the history of his family. The playwrights of the turn of the XX - XXI centuries, like the authors of the post-war period, see no future without memory of the past. 
Continuing the tradition of writers of the postwar period, young playwrights at the turn of the 20th and 21st centuries explore the theme of collective guilt, noting the inclination of modern young people to ousting the past and rejecting it. Amidst these things, the problem of German identity arises. The heroes of the plays give up on their parents, their language, their motherland, as if giving up on the past. They are no longer rebels at the beginning of the 20th century, not members of the uprisings of the $60 \mathrm{~s}$, and not even fighters for the unity of the late $80 \mathrm{~s}$, like their fathers, representatives of the older generation. Nowadays young people passively step aside, enjoying the benefits of civilization, but not thinking about their role in its development.

\section{Acknowledgements}

The work is performed according to the Russian Government Program of Competitive Growth of Kazan Federal University.

\section{References}

Dolzhansky, R. (2011). In Search of dialogue. Step 4. New German-language dramaturgy. - M .: Goethe German cultural center, 12 - 14.

Lisenko, A.R., \& Shevchenko, E.N. (2016). The history of Germany in contemporary German drama. Turkish online journal of design, art and communication, 6, 2409-2414,.

Pedersen, S.B. (2014). The aesthetics of a collapsing border: The fall of the Berlin Wall in German cinema. East Central Europe, 41(2-3), 254-276.

Prokhorova, T., \& Shamina, V. (2014). School for democracy: Interactive theater of soviet and the Post-Soviet Russia. Comparative Drama, 48(1-2), 59-73.

Schröder, J. (2006). "Postdramatisches Theater" oder "Neuer Realismus"? Drama und Theater der neunziger Jahre. Geschichte der deutschen Literatur von 1945 bis zur Gegenwart. München: Verlag C.H.Beck, 1080-1120.

Shevchenko, E. (2006). Rezeption des antiken Mythos im dramatischen Werk von Heiner Müller. Interliteraria, N. 5, Tartu (Estland): EAKL,168-183.

Shevchenko, E. (2009). The mythologization of German history in the drama of Boto Strauss "The Final Choir". National myth in literature and culture. Materials of the All-Russian Scientific Conference. - Kazan, 114-120.

Smyslova, E.V., \& Khabibullina, L.F. (2019). The Enderby novels by Anthony Burgess: The artist's concept. Humanities and Social Sciences Reviews, 7(6), 81-84.

Stockmann, N.-M. (2011). The ship will not come. STEP 4: New German-language dramaturgy in Russian. - M.: Goethe German cultural center; OGI, 423 - 474.

Takhtarova, S., Khairutdinov, R., \& Abuzyarova, D. (2019). Politeness in the German Ethnosocium: The Diachronic Aspect//Academic Journal of Interdisciplinary Studies, 8(2), 46-50.

Takhtarova, S.S., Abuzyarova, D.L., \& Kuzmina, O.D. (2019). Communication between Population of Germany and German-Speaking Switzerland: Intra-or Intercultural Communication?. Academic Journal of Interdisciplinary Studies, 8(2), 126-130.

Uberman, I. (2018). Kein Schiff wird kommen. URL: http://www.kulturtransfer.eu/index.php?option=com_content\&view=article\&id=55:nismomme-stockmann-kein-schiff-wird-kommen- regie-frank-abt-deutsches-theater $\&$ catid $=$ 3: theater \& Itemid = 4 (reference date: 09/20/2018).

Zavyalova, V., \& Shamina, V. (2016). Post-Perestroyka Challenges in Russian Political Drama.International Journal of Humanities and Culture. Special Issue, 682-687, July,. 